\title{
Empirical Effect: Flipped Classroom-Based E-Learning to Face Learning on Covid-19 Pandemic
}

\author{
Rizki Hardian Sakti ${ }^{1 *}$, Sukardi² iD \\ 1,2 State University of Padang, Padang, Indonesia \\ *Corresponding author: rizki.hardian29@gmail.com
}

\begin{abstract}
At the COVID-19 pandemic era in 2019-2020, all schools in the world faced a chalenging education situation. Innovative solutions were needed to optimize education efforts thus flipped classroom-based e-learning was implemented to maintain social distancing. The purpose of this study was to see the effectiveness or the empirical impact of the application of flipped classroom-based e-learning during the COVID-19 period. This study used a deductive approach using a choice of quantitative methods. The sample in this study was 30 students of SMKN 5 Padang. The instrument used in cognitive assessment was a test, while the effective and psychomotor assessment used an assessment rubric. We found that flipped classroom-based e-learning was effectively used in the learning process during the COVID-19 pandemic. Therefore, the flipped classroom-based e-learning can be effectively used as a media for distance learning.
\end{abstract}

Keywords: Flipped Classroom, COVID-19, E-Learning

$\begin{array}{lll}\text { History: } & & \text { Publisher: Undiksha Press } \\ \text { Received } & : \text { 31 January } 2021 & \text { Licensed: This work is licensed under } \\ \text { Revised } & : 25 \text { February } 2021 & \text { a Creative Commons Attribution 3.0 License } \\ \text { Accepted } & : 30 \text { March } 2021 & \text { CC () O) } \\ \text { Published } & : 25 \text { April } 2021 & \end{array}$

\section{Introduction}

The 2019-2020 school year was a challenging year for all schools in the world. The school year, which began in July 2019, must be ended in 2020 due to the COVID-19 pandemic case. In these unprecedented times, the world had to prepare themselves for the COVID-19 pandemic caused by the new SARS-CoV-2 virus (Wu et al., 2020). As a result, Indonesia saw a spike in cases occurring and limited their spread through social distancing. Much of the existing literature showed the impact of COVID-19 on teaching in various parts of the world, especially in terms of the difficulties, constraints, and challenges faced by governments, institutions, and stakeholders (Zhang et al., 2020; NFER, 2020; Huber \& Helm, 2020; Torales et al., 2020) as well as a description of how institutions and stakeholders were adapting to the new scenarios created by the COVID-19 pandemic (Moorhouse, 2020; Bao, 2020; Yan et al., 2021).

The spread of the COVID-19 pandemic has affected all sectors of society, especially education. The COVID-19 crisis caused an education crisis (Sepulveda-Escobar \& Morrison, 2020) which was unpredictable. School closures around the world have affected millions of students whose impact has not yet known. 'Emergency distance teaching' as a temporary solution (Bozkurt \& Sharma, 2020) has been adopted to reduce the effects of the pandemic on education. To reduce the spread of the COVID-19 pandemic, the Indonesian government decided to close all schools by March 2020. As such, schools and teachers are rapidly and abruptly adapting to what can only be described as an unprecedented educational emergency 
response (Bhaumik \& Priyadarshini, 2020). This situation raises many challenges, most importantly is the imbalance of access to electronic means (equipment and internet access) to ensure adequate online teaching for all children and adolescents. The use of online platforms has become a reality in today's learning (Bozkurt et al., 2020).

Distance learning is expected to overcome the problem of the learning process during the Covid-19 pandemic. To support its implementation (Gonzalez et al., 2020), the Ministry of Education developed many initiatives, namely a series of guidelines for schools to conduct online teaching and learning, and also provided advice and recommendations to schools and teachers to prepare strategies for developing distance teaching. Given the CDC's recommendation to cancel large conferences and limit the size of regular meetings, traditional models such as face-to-face should be considered (Rizvi et al., 2020). Current forms of learning have been challenged and like never before, especially given the current public health measures being taken for social distancing purposes to reduce the spread of COVID-19 (Peimani \& Kamalipour, 2021). As a result, disruption of educational activities can have a negative impact on the welfare of students (Bryson \& Andres, 2020). In the era of COVID-19, the need for innovative solutions to optimize education efforts is accelerating. Many programs have attempted to improvise with new technologies such as Zoom (Zoom, San Jose, California) and Slack (Slack Technologies, San Francisco, CA) (Hedberg et al., 2018).

Nevertheless, distance learning does not perform well in some schools and regions. Many students complain that distance learning is monotonous and boring, thus students have little desire to learn. The lack of teaching strategy and learning media made the students felt bored and less motivated. Therefore, it is possible to identify the media that contribute and recommend to support teachers and schools in implementing distance teaching well (OECD, 2020).

In 2018, the American College of Cardiology Fellows-in-Training Leadership Council proposed three new educational strategies to support the teachers in performing engaging distance learning: personalized learning, adaptive learning to real-world situations and feedback, and flipped classrooms (Narang et al., 2018). To maintain social distancing, researchers developed flipped classroom-based e-learning media. The development of the application of flipped classrooms in recent years explained that flipped classrooms were effective in improving student learning outcomes in Computer and Networking (Sakti \& Sukardi, 2020), algebra (Dassa et al., 2019), and physics (Trefzger \& Finkenberg, 2019). By May 2013, the network of flipped classroom users had more than 16,000 members worldwide (Sakti et al., 2020) which proved that flipped classrooms brought new perspectives in education.

However, previous research only focused on displaying video without combining material and other components in one media (Sakti \& Sukardi, 2020; Dassa et al., 2019; Trefzger \& Finkenberg, 2019). It still did not fully use the e-learning system and only provided videos from the YouTube application. If students had questions while watching videos, students could not ask the teacher directly. Therefore, the flipped classroom should be equipped with a discussion forum, where students can ask the teacher directly while watching videos. And, this study aimed to see the effectiveness of flipped classroom-based elearning in the learning process.

\section{Materials and Methods}

This research was based on a deductive approach using a choice of quantitative methods. Tests were conducted to test hypotheses and found new causal relationships by comparing before and after the use of flipped classroom-based e-learning. Students was given flipped classroom-based e-learning in the learning process. Furthermore, the class was 
evaluated to see increased academic achievement after learning by using flipped classroombased e-learning. Flipped classroom-based e-learning was held at Vocational High Schools in Padang for four weeks of the 2019/2020 school year. This study used one group pre-test and post-test experimental design. The pre-test and post-test were perfectly designed to demonstrate the effectiveness of flipped classroom-based e-learning. During the learning process, students used flipped classroom-based e-learning with scenarios before learning begins. First, students should watch the video provided in the media; after the learning begins, students would be given a case to solve, where the case was a problem that they must solve through live simulation.

The population of this study was all students majoring in computer network engineering at SMK Negeri 5 Padang. Random sample selection could be achieved at two levels. First, sampling was randomized by selecting subjects from a homogeneous population. Second, in this study, sampling was carried out using random sampling, where each student majoring in Network Computer Engineering at SMK Negeri 5 Padang had the same opportunity to be selected as the sample of this study. Thus, the research sample selected in this study was 1 group consisting of 30 students.

The instruments used in this study were tests and cognitive, affective, and psychomotor assessments. The cognitive assessment used tests, while affective and psychomotor assessments used a scoring rubric, for psychomotor assessments assessed from cases completed by students.

\section{Results and Discussion Results}

In this study, flipped classroom-based e-learning media has been developed. This media was tested for its effectiveness in learning during the COVID-19 pandemic. The effectiveness of flipped classroom-based e-learning is viewed from three aspects, namely cognitive, affective and psychomotor aspects. In cognitive research, the data was processed using the paired sample t-test, so the requirements for the t-test have to be met first. Here is the t-test requirement test.

Table 1. Normality Test

\begin{tabular}{llc}
\hline & & class \\
\hline $\mathrm{N}$ & & 30 \\
\hline Normal Parameters a & Mean & 81.84 \\
& Std. Deviation & 7,252 \\
\hline Most Extreme Differences & Absolute & 0.119 \\
& Positive & 0.109 \\
& Negative & -119 \\
\hline Kolmogorov-Smirnov Z & & 0.675 \\
Asymp. Sig. (2-tailed) & & 0.752 \\
\hline
\end{tabular}

The normality test (Table 1 ) shows that the p-value is 0.752 , which means that the value is more significant than 0.05 , so it can be concluded that the data is normally distributed. The paired sample t-test can be seen in Table 2 . 
Table 2. Results of the t-test

\begin{tabular}{|c|c|c|c|c|c|c|c|c|}
\hline & \multicolumn{5}{|c|}{ Paired Differences } & $\mathrm{t}$ & df & $\begin{array}{l}\text { Sig. (2- } \\
\text { tailed) }\end{array}$ \\
\hline & \multirow[t]{2}{*}{ Mean } & \multirow{2}{*}{$\begin{array}{c}\text { Std. } \\
\text { Devia } \\
\text { tion }\end{array}$} & \multirow{2}{*}{$\begin{array}{l}\text { Std. Mean } \\
\text { Error }\end{array}$} & \multicolumn{2}{|c|}{$\begin{array}{l}\text { 95\% Confidence Interval } \\
\text { of the Difference }\end{array}$} & & & \\
\hline & & & & Lower & Upper & & & \\
\hline $\begin{array}{l}\text { Pretest - } \\
\text { Posttest }\end{array}$ & 37.077 & 8.202 & 1.609 & 40.390 & 33.764 & 23.050 & 29 & 0.000 \\
\hline
\end{tabular}

T-test (Table 2) shows that the p-value is 0.000 , which means that the value is less than 0.05 , thus it can be concluded that significant differences occur before and after students use flipped classroom-based e-learning. The average value obtained from this t-test is 37.077 , and the standard deviation value is 8.202. The average pre-test and post-test scores of students can be seen in Table 3 .

Table 3. The Average Pre-test and Post-test Values

\begin{tabular}{ccc}
\hline No. & Category & Average \\
\hline 1 & Pretest & 73.5 \\
2 & Posttest & 82.4 \\
\hline
\end{tabular}

There is a difference in the mean score of students (Table 3) before and after using flipped classroom-based e-learning, where the mean score of students before using flipped classroom-based e-learning was 73.5 and after using flipped classroom-based e-learning amounted to 82.4, with the average score obtained by students was 80 , and the percentage of completeness classification reached $86.7 \%$. So it can be concluded that more than $85 \%$ percent of students have been able to meet the classical level of achievement, so it can be concluded that flipped classroom-based e-learning is effective in improving student learning outcomes. At the same time, the assessment of attitudes or affective can be seen in Table 4 .

Table 4. Attitude Assessment Results

\begin{tabular}{cccc}
\hline No. & Indicator & total & Percentage $(\%)$ \\
\hline 1 & A1 & 30 & 100 \\
2 & A2 & 25 & 83.3 \\
3 & A3 & 23 & 76.7 \\
4 & A4 & 22 & 73.3 \\
5 & A5 & 23 & 76.7 \\
6 & A6 & 24 & 80 \\
7 & A7 & 23 & 76.7 \\
\hline & Average & & 80.95 \\
\hline
\end{tabular}

The results of the attitude assessment (Table 4) show that 7 indicators are assessed in this attitude assessment rubric, where students get an average score of 80 on the attitude assessor. This means that flipped classroom-based e-learning is also effective in maintaining student attitudes during the learning process. Furthermore, the results of students' psychomotor assessments assessed from their performance in completing the cases given at each meeting can be seen in Table 5. 
Table 5. Performance Assessment Results

\begin{tabular}{|c|c|c|c|c|c|c|}
\hline \multirow{2}{*}{ No. } & \multirow{2}{*}{ Aspect } & \multicolumn{4}{|c|}{ Meeting no. } & \multirow{2}{*}{ Average } \\
\hline & & 1 & 2 & 3 & 4 & \\
\hline 1 & Solution Planning & 73.5 & 76.8 & 84.4 & 87.1 & 80.45 \\
\hline 2 & Preparation & 72.9 & 75.7 & 85.1 & 86.2 & 79,975 \\
\hline 3 & Process & 80.6 & 84.5 & 85.3 & 88.7 & 84,775 \\
\hline 4 & Result & 72.6 & 75.5 & 77.8 & 82.2 & 77,025 \\
\hline
\end{tabular}

The results of the psychomotor assessment (Table 5) show that four indicators are assessed, namely solution planning, preparation, process, and results that are assessed during 4 meetings. Their psychomotor scores at each meeting increased with an average score from 70 to more than 80 . This means that flipped classroom-based e-learning is also effective in improving student psychology during the learning process.

\section{Discussions}

The effect of flipped classroom-based e-learning is carried out to see how easy it is for students to understand the learning material using the flipped classroom-based e-learning. The effect of flipped classroom-based e-learning development can be seen in Computer and Basic Networking subjects, which is carried out by pre-test and post-test with 28 questions given to students before and after using flipped classroom-based e-learning.

Flipped classroom-based e-learning is designed so students can participate in online learning; this is one of the schools' efforts to heed the government's call for physical distancing to prevent the widespread of COVID-19. The flipped classroom-based e-learning trial results show that flipped classroom-based e-learning effectively improves students' cognitive, affective, and psychomotor abilities. This study's results are supported by Smith (2020) and Aş1ksoy \& Sorakin (2018), where the study states that the use of e-learning combined with flipped classrooms can improve student cognitive, affective, and psychomotor learning outcomes.

The effectiveness of learning flipped classroom using online varies between age groups. Generally, that is in children, especially younger ones, where these young children need a structured environment because children's focus and attention are more easily distracted. Therefore, to get the full benefit from online learning, there needs to be a concerted effort to provide a learning structure through video capabilities, and also the use of online learning by combining or engaging with the latest methods is more effectively used to focus student attention and motivate students to learn (Brewer \& Movahedazarhouligh, 2018).

Based on the data obtained, flipped classroom-based e-learning using t-test statistics, it can be interpreted that there are significant differences in student learning outcomes before and after using flipped classroom-based e-learning. Based on the student learning outcomes from both pre-test and post-test, it was found that more than $85 \%$ of students achieved the specified minimum completeness criteria. So, it can be concluded that flipped classroombased e-learning is effective for improving student learning outcomes and is used in learning.

The results of this study are supported by Chen et al. (2018) and Cheng et al. (2018) in their research which concludes that there is a statistically significant difference in student scores in the two groups, where students who use flipped classroom are better than students who use conventional methods. Based on the results, it can also be seen that this media has succeeded in improving student learning motivation, student learning variation, motivated teachers to deliver varied and systematic learning material to make it easier for students to understand learning. 
This pandemic has seriously disrupted the education system, which many things has lost its relevance. Karabulut-Ilgu et al. (2018) outline how schools continue to focus on traditional academic skills and rote learning rather than critical thinking and adaptability, which will be more important for future success. Could the move to online learning be a catalyst for creating new, more effective education methods? While many are also concerned that the rushed online transition may have hindered this goal, others who are pros have planned to make e-learning part of the 'new normal' and have experienced the benefits firsthand.

Also, many universities have successfully made the transition from conventional learning to online learning, and even by integrating with flipped classrooms. Such as Zhejiang University managed to get more than 5,000 online courses in just two weeks after the transition to using "DingTalk ZJU." Imperial College London began offering coronavirus science course, which is now the best-selling class launched in 2020 at Coursera.

For teachers and students with access to the right technology, there is evidence that online learning combined with flipped classrooms can be more effective in many ways. For example, several studies have shown that students retain $25-60 \%$ more material on average while studying online-flipped classrooms compared to only $8-10 \%$ in classrooms. This is mainly because students can learn online faster; e-learning requires $40-60 \%$ less time to study than in a traditional classroom because students can learn at their own pace, go back and reread, skip, or accelerate through their chosen concept (Lundin et al., 2018).

Flipped classroom-based e-learning enables teachers to reach students more efficiently and effectively through group chats, meeting video, voting, and document sharing, especially during this pandemic. Students also find it easier to communicate in this flipped classroom-based e-learning. This means that many researchers will continue to use flipped classroom-based e-learning even after the coronavirus ends because they believe traditional offline learning and e-learning can go hand in hand (Akçayır \& Akçayır, 2018; Hew \& Lo, 2018).

\section{Conclusion}

Flipped classroom-based e-learning This is designed so that students can take part in online learning. This is one of the schools' efforts to heed the government's call for physical distancing to prevent the widespread of COVID-19. The flipped classroom-based e-learning trial results show that flipped classroom-based e-learning effectively improves students' cognitive, affective, and psychomotor abilities. The implication of this research is to contribute to science to add references on effectiveness and flipped classrooms. In addition, we invite the researchers to examine the variables that have not been studied in the study to serve as guidelines for further refinement of this research.

\section{References}

Akçayır, G., \& Akçayır, M. (2018). The flipped classroom: A review of its advantages and challenges. Computers \& Education, 12(2018), 334-345. https://doi.org/10.1016/j.compedu.2018.07.021.

Aşıksoy, G., \& Sorakin, A. (2018). The effects of clicker-aided flipped classroom model on learning achievement, physics anxiety and student' perceptions. International Online Journal of Education and Teaching, 5(2), 334-346. https://doaj.org/article/06b7d717efd0466a84fe5a1ce2888414.

Bao, W. (2020). COVID-19 and Online Teaching in Higher Education: A Case Study of Peking University. Human Behavior and Emerging Technologies, 2(2), 113-115. https://doi.org/10.1002/hbe2.191.

Bhaumik, R., \& Priyadarshini, A. (2020). E-readiness of senior secondary school learners to 
online learning transition amid COVID-19 lockdown. Asian Journal of Distance Education, 15(1), 244-256. https://doi.org/10.5281/zenodo.3891822.

Bozkurt, A., Jung, I., Xiao, J., Vladimirschi, V., Schuwer, R., Egorov, G., \& Paskevicius, M. (2020). A global outlook to the interruption of education due to COVID-19 pandemic: Navigating in a time of uncertainty and crisis. Asian Journal of Distance Education, 15(1), 1-126. https://doi.org/10.5281/zenodo.3778083.

Bozkurt, A., \& Sharma, R. C. (2020). Emergency Remote Teaching in a Time of Global Crisis Due to CoronaVirus Pandemic. Asian Journal of Distance Education, 15(1), 16. https://doi.org/10.5281/zenodo.3878572.

Brewer, R., \& Movahedazarhouligh, S. (2018). Successful stories and conflicts: A literature review on the effectiveness of flipped learning in higher education. Journal of Computer Assisted Learning, 3(4), 409-416. https://doi.org/10.1111/jcal.12250.

Bryson, J. R., \& Andres, L. (2020). COVID-19 and rapid adoption and improvisation of online teaching: Curating resources for extensive versus intensive online learning experiences. Journal of Geography in Higher Education, 44(4), 608-623. https://doi.org/10.1080/03098265.2020.1807478.

Chen, K. S., Monrouxe, L., Lu, Y. H., Enq, C. C., Chang, Y. J., Chang, Y. C., \& Chai, P. Y. C. (2018). Academic outcomes of flipped classroom learning: A meta-analysis. Medical Education, 5(2), 910-924. https://doi.org/10.1111/medu.13616.

Cheng, L., Ritzhaupt, A. D., \& Antonenko, P. (2018). Effects of the flipped classroom instructional strategy on students' learning outcomes: A meta-analysis. Educational Technology Research \& Development, 6(7), 793-824. https://doi.org/10.1007/s11423018-9633-7.

Dassa, A., Khuluq, M. H., \& Assagaf, S. F. (2019). Exploring Flipped Learning in Elementary Linear Algebra Class. International Conference on Education, Science and Technology, 1387(2019), 1-6. https://doi.org/10.1088/1742-6596/1387/1/012142.

Gonzalez, T., Rubia, M. A. de la, Hincz, K. P., Comas-Lopez, M., Subirats, L., Fort, S., \& Sacha, G. M. (2020). Influence of COVID-19 confinement on students' performance in higher education. PLoS ONE, 15(10), 1-23. https://doi.org/10.1371/journal.pone.0239490.

Hedberg, H., Nouri, J., Hansen, P., \& Rahmani, R. (2018). A systematic review of learning through mobile augmented reality. International Journal of Interactive Mobile Technologies, 12(3), 75-85. https://doi.org/10.3991/ijim.v12i3.8404.

Hew, K. F., \& Lo, C. K. (2018). Flipped classroom improves student learning in health professions education: A meta-analysis. BMC Medical Education, 18(1), 1-38. https://doi.org/10.1186/s12909-018-1144-Z.

Huber, S., \& Helm, C. (2020). COVID-19 and Schooling: Evaluation, Assessment and Accountability in Times of Crises - Reacting Quickly to Explore Key Issues for Policy, Practice and Research with the School Barometer. Educational Assessment, Evaluation and Accountability, 32(2), 237-270. https://doi.org/10.1007/s11092-02009322-y.

Judd, J., Rember, B., Pellegrini, T., Ludlow, B., \& Meisner., J. (2020). This Is Not Teaching': The Effects of COVID-19 on Teachers. https://www.socialpublishersfoundation.org.

Karabulut-Ilgu, A., Jaramillo Cherrez, N., \& Jahren, C. T. (2018). A systematic review of research on the flipped learning method in engineering education. British Journal of Educational Technology, 4(9), 398-411. https://doi.org/10.1111/bjet.12548.

Lundin, M., Bergviken Rensfeldt, A., Hillman, T., Lantz-Andersson, A., \& Peterson, L. (2018). Higher education dominance and siloed knowledge: Systematic review of flipped classroom research. International Journal of Educational Technology in Higher Education, 15(1), 1-20. https://doi.org/10.1186/s41239-018-0101-6. 
Moorhouse, B. (2020). Adaptations to a Face-to-face Initial Teacher Education Course "Forced" Online Due to the COVID-19 Pandemic. Journal of Education for Teaching, 46(3), 1-3. https://doi.org/10.1080/02607476.2020.1755205.

Narang, A., Velagapudi, P., Rajagopalan, B., LeBude, B., Kithcart, A. P., \& Snipelisky, D. (2018). New Educational Framework to Improve Lifelong Learning for Cardiologists. J Am Coll Cardiol, 71(4), 454-462. https://doi.org/10.1016/j.jacc.2017.11.045.

NFER. (2020). Schools' Responses to Covid-19. Pupil Engagement in Remote Learning.

OECD. (2020). Education Responses to Covid-19: Embracing Digital Learning and Online Collaboration.

Peimani, N., \& Kamalipour, H. (2021). Online Education and the COVID-19 Outbreak: A Case Study of Online Teaching during Lockdown. Education Science, 11(2), 1-16. https:// doi.org/10.3390/educsci11020072.

Rizvi, S., Rienties, B., Rogaten, J., \& Kizilcec, R. F. (2020). Investigating variation in learning processes in a Future- Learn MOOC. Journal of Computing in Higher Education, 32(1), 162-181. https://doi.org/10.1007/s12528-019-09231-0.

Sakti, R. H., \& Sukardi. (2020). The Adventure With Cbi (Computer Based Instruction)Flipped Classsroom In Computer Networking Material. Journal of Information Technology and Computer Science (INTECOMS), 3(2), 95-101. https://doi.org/10.31539/intecoms.v3i2.1523.

Sakti, R. H., Sukardi, S., Giatman, M., Nazar, E., Wakhinuddin, W., \& Waskito, W. (2020). Flipped Classroom-Computer Based Instruction untuk Pembelajaran Revolusi Industri 4.0: Rancang Bangun dan Analisis Kebutuhan. Edumatic: Jurnal Pendidikan Informatika, 4(1), 63-72. https://doi.org/10.29408/edumatic.v4i1.2074.

Sepulveda-Escobar, P., \& Morrison, A. (2020). Online teaching placement during the COVID-19 pandemic in Chile: challenges and opportunities. European Journal of Teacher Education, 43(4), 587-607. https://doi.org/10.1080/02619768.2020.1820981.

Smith, R. (2020). Flipped Learning During a Global Pandemic: Empowering Students with Choice. International Journal of Multidisciplinary Perspectives in Higher Education, 5(1), 100-105. https://doi.org/10.32674/jimphe.v5i1.2428.

Torales, J., O’Higgins, M., Castaldelli-Maia, J. M., \& Ventriglio, A. (2020). The outbreak of COVID-19 coronavirus and its impact on global mental health. International Journal of Social Psychiatry, 66(4), 317-320. https://doi.org/ 1707.1/10707/20027067464002091155212212.

Trefzger, T., \& Finkenberg, F. (2019). Flipped classroom in secondary school physics education. IOP Conf. Series: Journal of Physics, 1286(2019), 1-8. https://doi.org/10.1088/1742-6596/1286/1/012015.

Wu, Y.-C., Chen, C.-S., \& Chan, Y.-J. (2020). The outbreak of COVID-19: An overview. Journal of the Chinese Medical Association, 83(3), 217-220. https://doi.org/ 10.1097/JCMA.0000000000000270.

Yan, Z., Gaspar, R., \& Zhu, T. (2021). How humans behave with emerging technologies during the COVID-19 pandemic? Human Behavior and Emerging Technologies, 3(1), 5-7. https://doi.org/10.1002/hbe2.249.

Zhang, W., Wang, Y., Yang, L., \& Wang., C. (2020). Suspending Classes without Stopping Learning: China's Education Emergency Management Policy in the COVID-10 Outbreak. Journal of Risk and Financial Management, 13(3), 1-6. https://doi.org/10.3390/jrfm13030055. 